\title{
PEMBERDAYAAN PEMUDA KARANG TARUNA MELALUI SINAU BARENG ADEMOS INDONESIA
}

\author{
Nurul Istifadhoh ${ }^{1}$ \\ Sekolah Tinggi Ekonomi Islam Kanjeng Sepuh Sidayu Gresik \\ isti@steikassi.ac.id
}

\begin{abstract}
Abstrak
Pemuda merupakan sosok yang sangat tepat dalam menghadapi perkembangan dunia, karena pemuda diilustrasikan sebagai seseorang yang memiliki semangat tinggi, bertenaga dan berintelektual. Peran pemuda dirasa sangat penting dalam membangun suatu negara. Hal ini dikarenakan pemuda memiliki andil yang cukup melalui perencanaan, pengembangan maupun strategi yang sangat dibutuhkan dalam pembangunan suatu negara. Hal inilah yang menjadi alasan mendasar pemerintah dengan menyiapkan pemuda dan sumber daya manusia lainnya supaya berkompeten dan berdaya saing. Lembaga pemberdayaan masyarakat ADEMOS Indonesia melalui program sinau bareng, ikut serta membantu peran pemerintah dalam peningkatan kapasitas pemuda di Bojonegoro. Melalui program sinau bareng, ADEMOS Indonesia mengajak pemuda di Bojonegoro untuk menjadi entrepreneur hebat dan ikut serta membangun desanya masing-masing. Sehingga akan menjadi pemuda yang memiliki rasa kepemilikan serta rasa tanggung jawab terhadap kemajuan desanya serta mampu berdaya saing.
\end{abstract}

Kata Kunci: Pemberdayaan, SDM, Pemuda, Ademos.

\begin{abstract}
Youth is a very appropriate figure in dealing with world developments, because youth is illustrated as someone who has high spirits, is powerful and intellectual. The role of youth is considered very important in developing a country. It was because the youth have a sufficient share through planning, development and strategies that are needed in the development of a country. therefore that is the fundamental reason for the government by preparing youth and other human resources to be competent and competitive. The community empowerment agency, ADEMOS Indonesia, through the sinau bareng program, participated in helping the government's role in increasing youth capacity in Bojonegoro. Through the sinau bareng program, ADEMOS Indonesia invites youth in Bojonegoro to become great entrepreneurs and participate in building their respective villages. with this program it is hoped that they will become young people who have a sense of ownership and a sense of responsibility towards the progress of their villages and are able to be competitive.
\end{abstract}

Keywords: Empowerment, Human Resources, Youth, Ademos. 


\section{PENDAHULUAN}

Di era globalisasi yang terjadi di seluruh belahan dunia, kemajuan suatu negara bergantung pada sumber daya manusia. Sumber daya manusia bersifat penting karena memiliki andil yang cukup besar dari segi perencanaan, pengembangan dan strategi untuk membangun suatu negara. Negara-negara yang berkembang memiliki sumber daya manusia yang berkompeten dan berdaya saing baik kalangan nasional maupun internasional. Begitupun juga dengan negara maju yang sumber daya manusianya sudah terlatih dan sangat profesional. Sehingga sumber daya manusia menjadi suatu hal yang memiliki peran utama dalam kemajuan suatu negara.

Indonesia memasuki era Industri 4.0 merupakan tantangan sekaligus peluang yang sangat besar. Dimana Indonesia harus siap dan mampu mensejajarkan dirinya dengan negara-negara lain dimana sebagian negaranya adalah negara maju. Implikasinya, pendekatan dan kemampuan baru diperlukan untuk membangun sistem produksi yang inovatif dan berkelanjutan. Pemerintah juga berupaya untuk meningkatkan kompetensi sumber daya manusia melalui program link and match antara pendidikan dengan industri. Menteri Perindustrian Airlangga Hartanto mengatakan bahwa: pertama, angkatan kerja di Indonesia harus terus belajar dan meningkatkan keterampilannya untuk memahami penggunaan teknologi internet of things. Kedua, pemanfaatan teknologi digital untuk memacu produktivitas dan daya saing bagi industri kecil dan menengah (IKM). Ketiga, industri nasional dapat menggunakan teknologi digital seperti Big Data, Autonomous Robots, Cybersecurity, Cloud, dan Augmented Reality. Keempat, inovasi teknologi melalui pengembangan startup dengan memfasilitasi tempat inkubasi bisnis (Kemenperin, 2017). Sehingga adanya Industri 4.0, Indonesia membutuhkan sumber daya manusia yang berkompeten dan mampu bersaing dalam kancah nasional maupun internasional.

Pemuda merupakan individu yang sedang mengalami perkembangan secara fisik dan sedang mengalami perkembangan emosional secara psikis. Pemuda memiliki peran yang sangat penting bagi pembangunan ekonomi baik saat ini maupun di masa yang akan datang. Pemuda dapat digambarkan sebagai titik tertinggi bagi perkembangan jiwa manusia, dimana pemuda bebas melakukan apa saja untuk membentuk dirinya. Bojonegoro merupakan daerah yang saat ini sedang berkembang, sebagian masyarakat banyak tertinggal akibat minimnya pendidikan dan akses tekhnologi. Hal ini berpengaruh terhadap ekonomi dan cara pola pikir masyarakat di Bojonegoro. Ekonomi yang rendah membuat sebagian pemuda di Bojonegoro memilih untuk 
bekerja mulai dari usia 15 tahun tanpa harus melanjutkan pendidikannya ke jenjang yang lebih tinggi. Lemahnya kondisi ekonomi membuat mereka harus memilih untuk mencari pendapatan lebih dengan merantau ke kota. Bagi mereka mencari pendapatan lebih itu lebih utama dari pada melanjutkan pendidikan, karena mereka harus segera meningkatkan kondisi ekonomi keluarganya. Selain itu, pemuda yang belum mendapatkan pekerjaan, mereka masih menganggur di rumah sambil menunggu panggilan dari perusahaan.

Hadirnya ADEMOS Indonesia menjadi peluang sekaligus solusi bagi para pemuda untuk menyiapkan masa depannya dengan baik dan jangka panjang. Hal ini dikarenakan ADEMOS Indonesia memiliki arah tujuan untuk melakukan pemberdayaan bagi pemuda yang mana dengan menggali potensi desa masing-masing pemuda. Oleh karena itu peneliti akan menggali tentang bagaimana pengaruh yang diterima pemuda setelah dilakukannya pemberdayaan ADEMOS Indonesia.

\section{LANDASAN TEORI}

Pemuda adalah kaum muda yang harus dilihat sebagai pribadi yang sedang berada pada taraf tertentu dalam perkembangan hidup manusia, dengan kualitas dan ciri tertentu, dengan peran, hak serta kewajiban tertentu, dan dengan potensi serta kebutuhan tertentu (Teddy Chandra, Tesis, 2014:1). Dalam proses pembangunan, pemuda merupakan pelopor perubahan dimanapun Ia berada dengan perannya sebagai pemberi kekuatan moral, kontrol sosial, dan agen pembaharuan dari fungsi dan kedudukanya yang srategis dalam pembangunan nasional. oleh sebab itu peningkatan kualitas hidup sumber daya manusia terutama pemuda harus lebih ditingkatkan untuk membekali mereka dalam membangun bangsa.

Menurut Suharto pemberdayaan mengarah kepada kemampuan seseorang, khususnya untuk kelompok yang rentan dan lemah sehingga mereka dapat memiliki kekuatan atau kemampuan dalam: a) memenuhi kebutuhan dasarnya sehingga mereka memiliki kebebasan (freedom), bukan hanya mereka bebas berpendapat namun juga bebas dari kelaparan, kebodohan dan kesakitan; b) menjangkau sumber-sumber produktif yang memungkinkan mereka untuk meningkatkan pendapatan bagi kebutuhannya dan memperoleh barang dan jasa yang mereka perlukan; c) berpartisipasi dalam proses pembangunan dan keputusan-keputusan yang mempengaruhi kehidupan mereka (Suharto, 2005).

Selanjutnya menurut Anthony Bebbington yang dikutip Mardikanto dan Soebianto, bahwasannya: "Pemberdayaan masyarakat merupakan upaya untuk meningkatkan harkat dan 
martabat lapisan masyarakat yang dalam kondisi sekarang tidak mampu untuk melepaskan diri dari perangkap kemiskinan dan keterbelakangan. Dengan kata lain, pemberdayaan adalah memampukan dan memandirikan masyarakat” (Mardikanto \& Soebianto, 2013). Pemberdayaan merupakan cara yang dilakukan pihak pemberdaya untuk menyampaikan ilmu pengetahuan, mendidik, melatih dan mendampingi masyarakat, serta mengembangkannya agar masyarakat mampu mandiri dan meningkatkan martabatnya.

\section{METODE PENELITIAN}

Penelitian ini dimaksudkan untuk mengidentifikasi dan memahami pemberdayaan pemuda oleh ADEMOS Indonesia yang ada di Bojonegoro. Oleh sebab itu, penelitian ini menggunakan metode pendekatan kualitatif. Pendekatan kualitatif yaitu memusatkan perhatiannya pada prinsip-prinsip umum yang mendasari perwujudan satuan-satuan gejala yang ada dalam kehidupan manusia (Ashshofa, 1996). Dalam pengambilan data, penelitian ini menggunakan teknik snowball sampling. Snowball sampling adalah teknik pengambilan sampel yang mula-mula jumlahnya kecil, kemudian membesar (Sugiyono, 2010). Jadi peneliti akan mengambil data melalui wawancara-wawancara dari informan ke informan yang lebih mendalam.

Data yang telah berhasil dikumpulkan selanjutnya akan dianalisis secara deskriptif kualitatif, yaitu analisis yang menghasilkan data deskriptif berupa kata-kata tertulis atau lisan dari orang-orang dan perilaku yang dapat diamati dengan metode yang telah ditentukan (Bungin, 2001). Tujuan dari metode ini adalah untuk membuat deskripsi atau gambaran mengenai objek penelitian secara sistematis, faktual dan akurat mengenai fakta-fakta, sifat-sifat serta hubungan antar fenomena yang diselidiki (Nazir, 2005).

\section{PEMBAHASAN}

ADEMOS Indonesia sebagai sarana yang dibutuhkan masyarakat guna untuk mewujudkan kesejahteran dengan pendidikan dan pendampingan melalui ilmu pengetahuan dan tekhnologi. ADEMOS Indonesia adalah singkatan dari Assosiasi untuk Demokrasi dan Kesejahteraan Sosial yang merupakan lembaga pemberdayaan masyarakat yang telah disahkan menurut Surat Keputusan Menteri Hukum dan Hak Asasi Manusia Republik Indonesia Nomor AHU-87.AH.01.06 Tahun 2008 sebagaimana terpublikasikan dalam Tambahan Berita Negara 
Republik Indonesia Tanggal 14 November 2008 Nomor 92. Sinau bareng merupakan model atau cara yang dilakukan ADEMOS Indonesia untuk kegiatan pemberdayaan.

ADEMOS Indonesia sebagai pelaku pemberdaya ingin mengajak masyarakat untuk memperoleh kesejahteraan dengan panduan dari peraturan menteri sosial no. 77/HUK/2010 mengenai pedoman dasar karang taruna. Terwujudnya kesejahteraan dilihat dari peningkatan ilmu pengetahuan dan teknologi serta kemandirian masyarakat. Hal ini yang menjadi tolak ukur keberhasilan ADEMOS Indonesia melalui program sinau bareng dalam memberdayakan masyarakat di Bojonegoro. Berlangsungnya kegiatan pemberdayaan masyarakat, ADEMOS bermitra dengan pemerintah kabupaten Bojonegoro, Blora dan Tuban, lembaga berdikari serta perusahaan ExxonMobile, Pertamina EP Cepu dan skk-migas supaya mampu berjalan dengan maksimal.

Adapun visi ADEMOS Indonesia dalam melakukan pemberdayaan ialah terwujudnya kemandirian. Berdirinya program pemberdayaan kepemudaan dilatar belakangi karena kurangnya peran pemuda dalam membangun daerah Bojonegoro. ADEMOS Indonesia dalam menjalin hubungan kepada pemuda karang taruna ialah melalui pendekatan kultural. Dengan pendekatan kultural, ADEMOS Indonesia telah mempelajari dan menjalankan budaya atau kebiasaan pemuda karang taruna untuk membangun chemistry. Selanjutnya metode yang digunakan ialah metode live in, yaitu setelah mengikuti kebiasaan pemuda karang taruna hubungan yang terjalin dibangun dengan sangat dekat seperti kekeluargaan.

Program sinau bareng untuk mewujudkan pemuda yang mandiri dilakukan melalui pemahaman organisasi dan entrepreneurship. Pertama adalah organisasi, pertama kali yang diarahkan oleh ADEMOS Indonesia ialah dengan memperjelas status karang taruna berdasarkan SK dari kepala desa serta merapikan administrasi organisasi karang taruna. Dengan administrasi yang rapi, benar dan terakui, organisasi karang taruna dapat menjadi organisasi yang terstruktur dan teradministratif yang memiliki posisi sesuai dengan perannya. Kedua ialah entrepreneurship, dalam membangun jiwa entrepreneurship pemuda diajak untuk menggali potensi yang ada di desanya masing-masing yang diberi sebutan UEP (Usaha Ekonomi Produktif) serta diajak mengelola peternakan dengan harapan pemuda mampu mengelola dan mengembangkannya dengan baik.

Demi kelancaran kegiatan UEP, hal pertama yang dilakukan adalah dengan melakukan analisis usaha, yang kedua mengadakan kerjasama antara pemuda karang taruna dengan pihak 
pengelola. Jadi secara tidak langsung ADEMOS Indonesia mengikat usaha itu, karena pemuda karang taruna adalah binaan dari ADEMOS Indonesia. Hal ini bertujuan agar usaha tersebut tetap ada. Ketiga mengadakan pendidikan dan pelatihan yaitu melakukan pelatihan manajemen usaha disertai pembukuannya. Sehingga pemuda karang taruna dapat dengan mudah mencatat semua administrasi yang terjadi serta mengerti tentang bagaimana menerapkan strategi untuk mengembangkannya.

Melihat rasio wirausaha di Indonesia menurut Badan Pusat Statistika (BPS) meningkat dari 1,67\% (2014) menjadi 3,1\% (2017), maka dapat disimpulkan peluang berwirausaha bagi pemuda cukup besar. Pemuda karang taruna memulai usahanya dengan mendirikan peternakan dan perikanan yang dimodali oleh ADEMOS Indonesia sebesar Rp 15.000.000,00 (lima belas juta rupiah) (A'yuni \& Muawanah, 2018). Modal tersebut kemudian dibelanjakan oleh pemuda karang taruna didampingi ADEMOS Indonesia dengan membelikan kambing dan bibit ikan yang siap untuk dikembangkan.

Demi mengasah jiwa entrepreneurship yang telah diberikan ADEMOS Indonesia, pemuda karang taruna dituntut agar bisa merawat dan mengembangkan usaha peternakan dan perikanan dengan sebaik-baiknya. Namun terkadang apa yang terjadi dalam perjalanan tidak selalu sejalan dengan apa yang telah kita rencanakan. Ada beberapa daerah yang peternakan dan perikanannya berhasil serta berkembang pesat, ada juga daerah yang peternakan dan perikanannya tidak berhasil sama sekali. Hal ini dapat menjadi tolak ukur mana daerah yang mampu mengelola peternakan dan perikanan tersebut dengan serius dan menguasai. Disamping entrepreneurship, sebagian pemuda karang taruna juga terasah kemampuannya dalam memimpin. Pemuda karang taruna ada yang dipercaya untuk mengelola Badan Usaha Milik Desa. Selain itu, organisasi karang taruna yang menjadi binaan ADEMOS Indonesia juga menjadi salah satu organisasi karang taruna terbaik di Kabupaten Bojonegoro.

Menurut ADEMOS Indonesia peran industri 4.0 sangat penting untuk menyelesaikan masalah sosial di masyarakat, yaitu dengan memperbaiki kualitas produk, meningkatkan desain produk, mengembangkan jaringan pemasaran online dan mendorong pemuda karang taruna untuk berkembang melalui aplikasi tekhnologi lainnya. Sasaran-sasaran usaha dan peningkatan kapasitas pemuda karang taruna atas binaan ADEMOS Indonesia diharapkan dapat memaksimalkan apa saja yang ada disekitarnya supaya terus berkembang. 


\section{PENUTUP}

Pada dasarnya pemuda yang tergabung dalam karang taruna sesuai dengan pedoman permensos no. 77/HUK/2010 yaitu mulai berusia 13 sampai 43 tahun. Usia yang sangat produktif untuk memulai langkah dalam mempersiapkan kehidupan jangka panjang. Hal ini merupakan alasan mengapa ADEMOS Indonesia melakukan pemberdayaan pemuda karang taruna, guna mempersiapkan dan meningkatkan kapasitas generasi penerus bangsa dengan sebaik-baiknya untuk pembangunan ekonomi Indonesia secara berkelanjutan.

Hadirnya ADEMOS Indonesia menjadi kebanggaan tersendiri bagi pemuda karang taruna dan pemerintah di Bojonegoro. Hal tersebut dibuktikan dengan adanya beberapa perubahan, salah satunya yaitu meningkatnya kapasitas pemuda karang taruna yang berkompeten dan berdaya saing; Bertambahnya jaringan untuk menggali serta memupuk ilmu pengetahuan, tekhnologi dan pengalaman; dan Munculnya rasa kepemilikan serta tanggung jawab pada diri pemuda atas tempat tinggalnya masing-masing;

Perubahan serta peningkatan mindset dan kapasitas pemuda karang taruna menjadi tolak ukur akan keberhasilan program sinau bareng ADEMOS Indonesia di Bojonegoro. Hal tersebut menjadi harapan serta motivasi ADEMOS Indonesia untuk berbuat lebih dan lebih baik lagi, guna untuk berbuat demi kemaslahatan umat di Bojonegoro.

\section{DAFTAR PUSTAKA}

Ashshofa, Burhan. 1996. Metode penelitian Hukum. Jakarta: Rineka cipta.

A’yuni, D., \& Muawanah, M. (2018). Optimalisasi Limbah Rumah Tangga Sebagai Peluang Berwirausaha. Indonesian Interdisciplinary Journal of Sharia Economics (IIJSE), 1(1), 41-48. https://doi.org/10.31538/iijse.v1i1.71

Bungin, Burhan. 2001. Metodologi Penelitian Sosial: Format-format Kuantitatif dan Kualitatif . Surabaya: Airlangga University Press.

Mardikanto, Totok dan Soebianto, Poerwoko. 2013. Pemberdayaan Masyarakat dalam Perspektif Kebijakan Publik. Bandung: Alfabeta.

Suharto, Edi. 2005. Membangun Masyarakat Memberdayakan Rakyat. Bandung: PT. Rafika Aditama. 
Chandra, Teddy. 2014. Pemberdayaan Pemuda Pengangguran Melalui Usaha Industri Kecil Kerajinan Sarung Tenun [Studi pada Pengrajin Tenun di Kelurahan Wanarejan Utara Kabupaten Pemalang]. Semarang: Universitas Negeri Semarang.

Nazir, Moh. 2005. Metode Penelitian. Bogor: Penerbit Ghalia Indonesia.

Sawitri, Nurul. 2014. PartisipasI Pemuda dalam Program Karang taruna Desa [Studi pada Pemuda di Dusun Kupang Kidul Desa Kupang Kecamatan Ambarawa]. Semarang; Universitas Ngeri Semarang.

Sugiyono. 2010. Metode Penelitian Bisnis: Pendekatan Kuantitatif, Kualitatif dan R\&D. Bandung: Alfabeta.

http://www.kemenperin.go.id/artikel/17565/Empat-Strategi-Indonesia-Masuk-RevolusiIndustri-Keempattertentu

https://www.antaranews.com/berita/866097/peran-pemuda-dalam-membangun-bangsadinilai-semakin-beragam 